\title{
A COMMENT ON THE PUBLIC MORALS EXCEPTION IN INTERNATIONAL TRADE AND THE EC - SEAL PRODUCTS CASE: MORAL IMPERIALISM AND OTHER CONCERNS
}

\author{
Elizabeth Whitsitt ${ }^{*}$
}

\begin{abstract}
Public morality concerns are ripe for consideration in international trade disputes. The long-awaited WTO decisions in EC - Seal Products afforded the world's leading international trade arbiter the opportunity to consider, among other things, application of the public morals exception in GATT and the TBT Agreement to the EU's 2009 ban on the importation and marketing of seal products. While the EU's seal products ban was ultimately held to be discriminatory and thus did not meet the requirements of GATT Article XX's chapeau, the reasoning enunciated by the Appellate Body (and WTO Panel) would have allowed the ban as being justified under the right to protect public morals. That same reasoning, however, lacked a measured analysis weighing the competing moral considerations about animal (seal) welfare against protecting the traditional and cultural practices (seal hunting) of impacted indigenous communities with short shrift being paid to the indigenous community interests. In result, the WTO's most recent rulings on public morals effectively legitimizes the moral imperialism inherent in the EU's seal products ban.
\end{abstract}

\section{Keywords}

Trade law, environmental law, public morals exception

\section{Introduction}

Public morality concerns are ripe for consideration in trade disputes before the World Trade Organization (WTO). In the recent EC - Seal Products decisions from the WTO Panel and Appellate Body $(A B),{ }^{1}$ the world's leading international trade arbiter was asked to sanction the EU's 2009 ban on the importation and marketing of seal products (EU Seal Regime). The ban was ostensibly

\footnotetext{
Assistant Professor, University of Calgary, Faculty of Law.

1 Panel, European Communities - Measures Prohibiting the Importation and Marketing of Seal Products, WTO Docs WT/DS400/R, WT/DS401R (25 November 2013) (EC - Seal Products); AB, European Communities - Measures Prohibiting the Importation and Marketing of Seal Products WT/DS400/AB/R, WT/DS401/AB/R (22 May 2014) (EC - Seal Products).
}

Copyright $\odot$ the Author(s).

This work is licensed under a Creative Commons Attribution-NonCommercial-NoDerivs 3.0 License. 
implemented to address the EU's moral concerns about the welfare of seals, but was criticised harshly by Canada, where sealing is a vital cultural practice for its indigenous Inuit communities, as well as by Norway. Thus the stage was set for a significant debate, pitting animal rights activists seeking to stop certain seal hunting practices against indigenous communities (actually, their respective state governments) seeking to protect their long held traditional and cultural seal hunting practices.

The EU Seal Regime is delineated in two pieces of legislation-the Framework Regulation and the Implementation Regulation. ${ }^{2}$ Briefly summarised, the measure bans the sale of seal products in all EU member states, subject to certain explicit and implicit exceptions. Explicitly, the measure permits the sale of seal products in the EU market if those products are: (i) derived from hunts carried out by indigenous peoples (IC Exception), ${ }^{3}$ (ii) derived from hunts that were conducted for the sustainable management of marine resources, (iii) or personally imported into the EU by travellers. ${ }^{4}$ Implicitly, the measure also permits the import of seal products into the EU for processing and re-export, a convenient loophole that protects commercial interests within the EU.

In 2011, Canada and Norway commenced WTO dispute settlement proceedings against the EU over the EU Seal Regime. The primary claims were that the

2 Regulation (EC) No 1007/2009 of the European Parliament and of the Council of 16 September 2009 on Trade in Seal Products, 2009 OJ L 286, 36 (Framework Regulation); Commission Regulation (EU) No 737/2010 of 10 August 2010 laying down detailed rules for the implementation of Regulation (EC) No 1007/2009 of the European Parliament and of the Council on trade in seal products (Implementing Regulation) (collectively EU Seal Regime).

3 Framework Regulation, Art 3(1), which states: 'The placing on the market of seal products shall be allowed only where the seal products result from hunts traditionally conducted by Inuit and other indigenous communities and contribute to their subsistence. These conditions shall apply at the time or point of import for imported products.'

4 See Framework Regulation, Art 3(2) which reads:

(a) the import of seal products shall also be allowed where it is of an occasional nature and consists exclusively of goods for the personal use of travellers or their families. The nature and quantity of such goods shall not be such as to indicate that they are being imported for commercial reasons;

(b) the placing on the market of seal products shall also be allowed where the seal products result from by-products of hunting that is regulated by national law and conducted for the sole purpose of the sustainable management of marine resources. Such placing on the market shall be allowed only on a non-profit basis. The nature and quantity of the seal products shall not be such as to indicate that they are being placed on the market for commercial reasons. 
Seal Regime was discriminatory and posed an unnecessary obstacle to trade contrary to the General Agreement on Tariffs and Trade $(G A T T)^{5}$ and the Agreement on Technical Barriers to Trade (TBT Agreement). ${ }^{6}$ After hearing the case and subsequent appeal, respectively, both the WTO Panel and the AB determined (albeit for different reasons) that the EU Seal Regime is justified under the right to protect public morals, specifically on the grounds of protecting animal welfare. Both bodies also found, however, that the purported Inuit ${ }^{7}$ and other indigenous communities ${ }^{8}$ exception to the ban was discriminatory in the way it is applied, and should be modified in order to fully comply with the EU's international trade obligations.

The WTO Panel focused its analysis on the TBT Agreement. ${ }^{9}$ Specifically, it found that the IC Exception was discriminatory as it was designed to benefit seal products harvested by Greenland's Inuit communities over Canadian Inuit communities. ${ }^{10}$ At the same time, the Panel determined that the EU was entitled under Article 2.2 of the TBT Agreement to ban the importation and marketing of seal products because it was aimed at, and made some contribution toward, addressing EU public moral concerns over animal welfare. ${ }^{11}$ Moreover, it determined that alternative and less restrictive measures (i.e. labeling seal products harvested through a humane hunt) were not reasonably available given

${ }^{5}$ General Agreement on Tariffs and Trade, 30 October 1947, 58 UNTS 187 (GATT).

${ }^{6}$ Marrakesh Agreement Establishing the World Trade Organization, 15 April 1994, 1867 UNTS 3, Annex 1 (Agreement on Technical Barriers to Trade) (TBT).

7 See Framework Regulation, Art 2(4) where 'Inuit' is defined as 'indigenous members of the Inuit homeland, namely those arctic and subarctic areas where, presently or traditionally, Inuit have aboriginal rights and interests, recognised by Inuit as being members of their people and includes Inupiat, Yupik (Alaska), Inuit, Inuvialuit (Canada), Kalaallit (Greenland) and Yupik (Russia)'.

${ }^{8}$ See Implementing Regulation, Art 2(1) where 'Other indigenous communities' is defined as 'communities in independent countries who are regarded as indigenous on account of their descent from the populations which inhabited the country, or a geographical region to which the country belongs, at the time of conquest or colonization or the establishment of present State boundaries and who, irrespective of their legal status, retain some or all of their own social, economic, cultural and political institutions'.

9 For a brief synopsis and comment on these developments see E Whitsitt \& N Bankes, 'The WTO Panel Decision on the EU's Rules on the Marketing of Seal Products: Who Won and Who Lost?' (ABlawg, 10 January 2014), <http://ablawg.ca/2014/01/10/the-wto-panel-decision-onthe-eus-rules-on-the-marketing-of-seal-products-who-won-and-who-lost/> [accessed $31 \mathrm{Oc}$ tober 2014].

${ }^{10}$ Panel, EC - Seal Products, above n 1, paras 7.303-315, 7.460.

${ }^{11}$ Ibid, paras 7.415 et seq. Note the Panel concedes that public morals are a legitimate objective notwithstanding that TBT Art 2.2 of the TBT Agreement does not expressly refer to public morals. 
the challenges associated with the establishment of appropriate standards and any subsequent implementation and monitoring of such a program. ${ }^{12}$ All of these findings heavily influenced the Panel's brief analysis of the EU Seal Regime under GATT. While the Panel determined that the EU's ban on the importation and marketing of seal products could be justified as 'necessary to protect public morals', it also found that the EU Seal Regime did not meet the requirements of GATT Article XX's chapeau due to the discriminatory design and application of the IC Exception. ${ }^{13}$

While the $\mathrm{AB}$ subsequently upholds some of the Panel's findings on appeal, the $\mathrm{AB}$ departs from the WTO Panel's reasoning in significant ways. Most importantly, the $\mathrm{AB}$ takes steps to clarify and distinguish between the analyses of measures challenged under GATT versus the TBT Agreement. ${ }^{14}$ Overturning one of the fundamental findings of the WTO Panel, the AB held that the EU Seal Regime is not a 'technical regulation' as defined in Annex 1.1 of the TBT Agreement. ${ }^{15}$ As a result, it was held that the TBT Agreement does not apply and the AB's decision on the validity of the EU's Sealing Regime turns entirely upon GATT.

In its final report, the $\mathrm{AB}$ confirmed that the IC Exception violated GATT Article I:1 on grounds that the EU Seal Regime detrimentally affects the conditions of competition for Canadian and Norwegian seal products when compared to Greenlandic seal products. ${ }^{16}$ The AB further upheld the Panel's conclusion that the EU could provisionally justify its Seal Regime on public moral grounds. However, it went on to find that the EU Seal Regime, in particular the IC Exception, did not meet the strictures of the chapeau in GATT Article XX. ${ }^{17}$

Given the apparent competing public policies or more specifically public moral concerns, one might have expected the WTO Panel and subsequently the $\mathrm{AB}$ to conduct a measured analysis weighing moral considerations about seal welfare against protecting the traditional and cultural practices of communities that have been hunting seals as a way of life for centuries. The WTO Panel and $\mathrm{AB}$, however, manage to avoid such complexities with short shrift paid to the

\footnotetext{
12 Ibid, paras $7.493 \mathrm{ff}$.

13 Ibid, paras 7.630-7.639, 7.644-7.651.

${ }^{14}$ For a brief synopsis and comment on these developments see E Whitsitt \& N Bankes, 'Sealing: It's a moral not a technical issue and animals outweigh indigenous communities,' (ABlawg, 12 June 2014) <http://ablawg.ca/2014/06/12/sealing-its-a-moral-not-a-technical-issueand-animals-outweigh-indigenous-communities/> [accessed 31 October 2014].

${ }^{15} \mathrm{AB}$, EC - Seal Products, above n 1, paras 5.58-5.59.

${ }^{16}$ Ibid, paras 5.90, 5.95.

17 Ibid, paras 5.320, 5.337-5.338.
} 
Inuit and indigenous community interests in the case. As a result, the WTO's most recent rulings on public morals effectively legitimises the moral imperialism inherent in the EU Seal Regime, whereby the dominant EU culture defines and imposes its morality onto foreign indigenous communities without meaningful consideration of their interests and in the face of effectively destroying their ability to benefit from traditional and cultural seal hunting practices.

This comment on the EC - Seal Products decision is organised as follows. This Introduction (1) section is followed by an explanation on the importance of construing objectives under the public morals exception (2) along with a brief overview of the WTO Panel and $\mathrm{AB}$ decisions interpreting the objectives of the EU Seal Regime (3). The comment then proceeds to argue that the decision-makers' narrow construction of the objectives of the EU Seal Regime result in conflicting judicial authorities (4) and is contrary to the text of the legislative instruments outlining the EU Seal Regime (5). Finally, this comment asserts that the WTO Panel's and AB's lack of a clear and balanced identification of all of the EU Seal Regime's objectives results in analytical shortcomings that are critical to the analysis of the public morals exception (6) and legitimises a measure that operates in a morally imperialistic manner (7). The final section provides concluding remarks (8).

\section{The Importance of Construing Objectives under GATT Article XX(a)}

In recognition of a WTO member state's right to implement domestic regulations, many of the covered agreements of the WTO contain exceptions or limitation clauses, which allow for implementation of trade-restrictive policies in circumstances that are thought to be necessary or appropriate to achieve that state's legitimate objectives. ${ }^{18}$ GATT Article XX is one such example. An assessment of a claim of justification under Article XX involves a two-tiered analysis, in which a measure must be provisionally justified under one of the subparagraphs of Article XX and then appraised under its chapeau. ${ }^{19}$ For a measure to be provisionally justified under one of the subparagraphs, WTO jurisprudence confirms that the

\footnotetext{
${ }^{18}$ See e.g. GATT Art XX; TBT Art 2.2.

${ }^{19} \mathrm{AB}$, United States - Standards for Reformulated and Conventional Gasoline, WTO Doc WT/DS2/AB/R (29 April 1996) 22 (US - Gasoline); AB, United States - Import Prohibition of Certain Shrimp and Shrimp Products, WTO Doc WT/DS58/AB/R (12 October 1998) paras 119-120. See also AB, United States - Measures affecting the Cross-Border Supply of Gambling and Betting Services, WTO Doc WT/DS285/AB/R (7 April 2005) para 292 (referencing a two-tiered approach
} 
challenged measure must 'address the particular interest specified in that paragraph' and that there must be a sufficient nexus between the measure and the interest protected. ${ }^{20}$ A WTO member wishing to justify a measure under GATT Article XX(a) must demonstrate that it has adopted or enforced that measure 'to protect public morals' and that the measure is 'necessary' to protect those morals.

As the $\mathrm{AB}$ has explained on various occasions, the necessity analysis involves 'weighing and balancing' a series of factors, including the importance of the objective and the contribution of the measure to that objective. ${ }^{21}$ Thus, while it seems trite to say, one cannot stress enough the importance of properly construing the objectives of a measure when assessing whether it is a justifiable violation of WTO law. Nonetheless, as elaborated on below, the WTO Panel and $\mathrm{AB}$ narrowly construed the objectives of the EU Seal Regime in this case an interpretive error that resulted in the existence of conflicting jurisprudence as to the primary or main rationale of the EU Seal Regime and perhaps more importantly, is inconsistent with the very text of the EU Seal Regime.

\section{The WTO Panel and Appellate Body Narrowly Construe the Objectives of the EU Seal Regime}

In assessing the legality of the EU Seal Regime, both the WTO Panel and the $\mathrm{AB}$ were required to identify the ban's objectives. For the WTO Panel, this discussion occurred in its assessment of the EU Seal Regime as an unnecessary obstacle to trade under Article 2.2 of the TBT Agreement ${ }^{22}$ and subsequently informed its analysis of the public morals exception under GATT Article XX(a) ${ }^{23}$ In its analysis, the WTO Panel narrowly construed the objectives of the EU Seal

\footnotetext{
to similar justification provisions under GATS) (US - Gambling).

${ }^{20} \mathrm{AB}$, US - Gambling, ibid.

${ }^{21} \mathrm{AB}$, Korea - Measures Affecting Imports of Fresh, Chilled and Frozen Beef, WTO Doc WT/DS161/AB/R WT/DS169/AB/R (11 December 2000) para 164 (Korea - Beef); AB, US Gambling, ibid, para 306; AB, Brazil - Measures Affecting Imports of Retreaded Tyres, WTO Doc WT/DS322/AB/R (3 December 2007) para 182 (Brazil - Retreaded Tyres). Other factors to consider under the necessity test include the trade-restrictiveness of the challenged measure and whether there are less trade-restrictive alternatives that could make a similar contribution to the challenged measures objectives: see e.g. AB, US - Gambling, ibid, para 307 (referring to Korea Beef, para 166). See also AB, United States - Measures Concerning the Importation, Marketing and Sale of Tuna and Tuna Products, WTO Doc WT/DS381/AB/R (16 May 2012) para 321 (referring to US - Gambling, ibid, para 307).

${ }^{22}$ Panel, EC - Seal Products, above n 1, paras 7.372-7.411.

${ }^{23}$ Ibid, para 7.631.
} 
Regime. Unlike the issue of seal welfare, the evidence submitted by the EU did not show that the interests addressed by the IC Exception were grounded in the concerns of EU citizens (i.e. public morals). As a result, the WTO Panel determined that the EU Seal Regime as a whole was intended to protect animal welfare with the IC Exception, among other exceptions, conceptualised as ameliorative provisions included in the measure solely as part of the political maneuvering necessary to pass the legislation within the EU. ${ }^{24}$

On appeal, the AB supported the WTO Panel's strict characterisation of the objectives informing the EU Seal Regime. Indeed, the $\mathrm{AB}$ took great pains to explain that the WTO Panel did not identify seal welfare as the only motivation behind the EU Seal Regime. ${ }^{25}$ According to the AB, the WTO Panel concluded that the main or principal rationale for adopting the EU Seal Regime was to address public concerns on seal welfare. Moreover, the $\mathrm{AB}$ found that 'although the panel rejected the contention that [indigenous communities] and other interests reflected independent objectives of the EU Seal Regime, [it did] not understand the Panel to have excluded the role of [indigenous communities] and other interests in the design and implementation of the measure. ${ }^{26}$

\section{Narrowly Construing the Objectives of EU Seal Regime Needlessly Results in Conflicting Authorities}

In contrast to the WTO Panel's and AB's conclusion that the main or principal objective of the EU Seal Regime was to protect seal welfare, other judicial authorities have determined that the principle objective of the EU Seal Regime was regulatory harmonisation. In Inuit Tapiriit Kanatami and Others v European Commission, seal harvesters comprising a coalition of Inuit bands and aboriginal individuals, as well as industry associations from Canada, Norway and Greenland challenged the validity of the Framework and Implementing Regulations under EU law. ${ }^{27}$ In dismissing that action, the General Court upheld both Regulations

\footnotetext{
${ }^{24}$ Ibid, paras 7.385-402.

${ }^{25}$ AB, EC - Seal Products, above n 1, paras 5.144-5.148.

${ }^{26} \mathrm{Ibid}$.

${ }^{27}$ See e.g. Case T-18/10, Inuit Tapiriit Kanatami and Others $v$ Parliament and Council, Order of the General Court of 6 September 2011 (currently under appeal); Case T-526/10, Inuit Tapiriit Kanatami and Others v. European Commission, Judgment of the General Court (Seventh Chamber) of 25 April 2013 (Tapiriit v EC).
} 
on the basis of Article 95 of the EC Treaty and observed that the principle objective of the EU's Regulations is not to safeguard the welfare of animals but to improve the functioning of the internal market. ${ }^{28}$ Particularly compelling for the Court were recitals 6 to 8 of the EU's Framework Regulation, which, according to the General Court, evinced a decision by EU legislators to harmonise rules about the commercial activities associated with seal products within the Union. ${ }^{29}$ This supported the Court's conclusion that the EU's measure was not ultra vires the power of the Union legislature. ${ }^{30}$ Finding that the applicants' arguments were grounded on 'the erroneous assertion that the objective of the regulation is the protection of animal welfare', the Court concluded that the EU Seal Regime was consistent with the principle of subsidiarity. ${ }^{31}$

It is not clear why this decision of the EU General Court and the objective of regulatory harmonisation were not addressed in the WTO decisions on the legality of the EU Seal Regime. In its report, the Panel indicates that neither Norway nor Canada pressed the issue. ${ }^{32}$ There is also no indication that the parties raised arguments discussing this point on appeal, a fact that likely explains its absence the AB's decision on objectives. Indeed, the existence of such conflicting decisions is a natural consequence of international law's increasingly fragmented character. ${ }^{33}$ This is not to say that the WTO Panel and AB were bound by the Tapiriit $v$ EC case or that they needed to enforce-or even endorse-the ruling the EC General Court. ${ }^{34}$ Still, it seems odd that such a decision would be ignored-especially when it rules on a matter (i.e. the objectives of EU's ban on seal products) so crucially important and relevant to the WTO's decision about the public morals justification of the EU Seal Regime. It seems plausible that WTO decision-makers could at the very least have discussed the ruling of the EC

\footnotetext{
${ }^{28}$ See Tapiriit $v$ EC, ibid, para 35.

${ }^{29}$ Ibid, para 39.

${ }^{30}$ Ibid, paras 79-102.

31 Ibid, para 83.

32 Panel, EC - Seal Products, above n 1, para 7.389.

${ }^{33}$ See Report of the Study Group of the International Law Commission, Fragmentation of International Law: Difficulties Arising from Diversification and Expansion of International Law, ILC, $58^{\text {th }}$ Sess, UN Doc A/CN.4/L.682 (2006).

34 The jurisdiction of WTO panels is limited to claims under WTO Agreements. A number of provisions in the Dispute Settlement Understanding support this proposition. See e.g. Marrakesh Agreement Establishing the World Trade Organization, 1869 UNTS 401, Annex 2, Understanding on Rules and Procedures Governing the Settlement of Disputes (DSU), Arts 1.1, 3.2, 7.111. See also DSU Art 17.6 which clarifies that appeals must be limited to issues of law and interpretations addressed by the relevant panel.
} 
General Court as part of the applicable law in this case, if only to acknowledge that the EU Seal Regime was put in place to address numerous objectives. ${ }^{35}$

\section{Narrowly Construing the Objectives of the EU Seal Regime is Inconsistent with the Text of its Constituting Legislation}

Contrary to WTO Panel and AB decisions, which in effect determined that the main or principal objective of the EU Seal Regime was to protect seal welfare, the text of the Framework Regulation highlights the fact that there are multiple objectives to the EU Seal Regime. The Framework Regulation comprises 21 preambular paragraphs and 8 operative articles. The preamble is important in ascertaining the premises and intent of the regulation as well as establishing the legal basis for the Framework Regulation in EU law. Those introductory paragraphs demonstrate that the EU's law is intended to address a number of objectives, including but certainly not limited to, the protection of seal welfare.

The preamble begins by reciting the history of the community's concerns with respect to sealing (cruel hunting of sentient beings) and the adoption of the prohibition on imports of skins from harp seal and hooded seal pups in $1983 .^{36}$ Animal welfare concerns are also mentioned in other paragraphs of the preamble, which articulate the concerns raised by citizens within the EU and governments over the hunting of seals. ${ }^{37}$ Thus, it is unquestionable that one of the propelling forces behind the EU Seal Regime is public unease about the potential for seal harvesting to perpetuate cruel and inhumane treatment of animals and a desire to prevent such treatment wherever possible. Nonetheless, moral concerns about animal welfare are not the only objective addressed within the EU Seal Regime.

Another objective also identified in the Framework Regulation is avoiding the potential for inconsistent regulation in the trade of seal products within the EU. In particular, the preamble notes that member states are passing or intend to pass domestic measures that regulate trade in seal products and expresses the

\footnotetext{
${ }^{35}$ Nothing in the DSU or WTO rules precludes a panel from addressing other relevant judicial decisions in deciding the case before it (see DSU Arts 7.1, 7.2). This proposition in relation to the applicability of international rules to WTO law is hotly debated, however. See e.g. Joost Pauwelyn, Conflict of Norms in Public International Law: How WTO Law Relates to Other Rules of International Law (2003) 466-72 \& n 82.

${ }^{36}$ Framework Regulation, paras 1-2.

${ }^{37}$ Ibid, paras 4-5.
} 
concern that such a patchwork of initiatives may 'adversely affect the operation of the internal market in products which contain or may contain seal products, and constitute barriers to trade in such products. ${ }^{38}$ More particularly, the preamble acknowledges that this potential for disjointed regulation may affect trade in goods where consumers cannot readily tell if such goods include ingredients from seals, such as leather goods or Omega- 3 capsules and oils. ${ }^{39}$ Thus, in recognition of both moral concerns about animal welfare and promote harmonisation of the EU's internal market rules, the preamble refers to the general rule prohibiting the placement of seal products on the market. ${ }^{40}$ The preamble effectively acknowledges that this is an extreme solution but justifies it on the basis of assessments conducted by the European Food Safety Authority, which indicate that the conditions of the seal hunt cannot provide assurances that seals will only (i.e. exclusively) be harvested in a manner that satisfies concerns as to animal welfare. $^{41}$ For the same reason labeling solutions are also ostensibly unable to offer the requisite assurances.

Balanced against the objectives of protecting animal welfare and promoting regulatory harmonisation within the EU, the preamble of the Framework Regulation further articulates the need to facilitate trade in seal products under certain conditions. One such condition is the IC Exception. Unlike the marine resource management and travellers exceptions, which receive only brief mention in the preamble, the IC Exception features more prominently within the preamble. The rationale for the IC Exception is outlined in paragraph 14 of the preamble:

The fundamental economic and social interests of Inuit communities engaged in the hunting of seals as a means to ensure their subsistence should not be adversely affected. The hunt is an integral part of the culture and identity of the members of the Inuit society, and as such is recognized by the United Nations Declaration on the Rights of Indigenous Peoples. Therefore, the placing on the market of seal products which result from hunts traditionally conducted by Inuit and other indigenous communities and which contribute to their subsistence should be allowed.

Accordingly, the EU legislators recognised the moral concern of preserving seal hunts by Inuit and other indigenous communities. They also did so by

\footnotetext{
${ }^{38}$ Ibid, paras 5-6.

${ }^{39}$ Ibid, para 7.

${ }^{40}$ Ibid, para 10.

${ }^{41}$ Ibid, para 11.
} 
expressly referencing the United Nations Declaration on the Rights of Indigenous Peoples $(U N D R I P)$, which among other things, recognises the rights of indigenous peoples 'to maintain and develop their political, economic and social systems or institutions, to be secure in the enjoyment of their own means of subsistence and development, and to engage freely in all their traditional and other economic activities.' ${ }^{42}$ Indeed the EU argued before both the WTO Panel and the AB that EU law-makers considered that the subsistence of Inuit and other indigenous communities and the preservation of the their cultural identity outweigh, from a moral point of view, the risk of suffering inflicted upon seals as a result of inhumane hunts conducted by those communities. ${ }^{43}$ In determining that the IC Exception was discriminatory, the WTO Panel acknowledged that 'seal hunting represents a vital element of the tradition, culture and livelihood of Inuit and indigenous communities. ${ }^{44}$ However, it paid short shrift to the international instruments recognising those rights and rejects the EU's arguments tying the economic and social interests of Inuit and indigenous communities to moral concerns. ${ }^{45}$ The $\mathrm{AB}$ does little to remedy this failing and instead defers to the WTO Panel's margin of discretion to weigh the evidence and make appropriate findings about the objectives of the EU Seal Regime. ${ }^{46}$

For similar reasons as those discussed above in relation to the Tapiriit $v$ EC case, the decisions of the WTO Panel and $\mathrm{AB}$ regarding the objectives of the EU Seal Regime are troubling. Given the EU Seal Regime's explicit reference to the UNDRIP and the EU's arguments that indigenous rights enshrined in that document and other international law instruments outweigh seal welfare, one might have expected the WTO decision-makers to consider those instruments when interpreting the objectives of the EU Seal Regime. ${ }^{47}$ Indeed, a failure to do so at the panel level is arguably a reviewable error of law. While the UNDRIP

\footnotetext{
${ }^{42}$ UN Declaration on the Rights of Indigenous Peoples, [without reference to a Main Committee (A/61/L.67 and Add.1)] GA Res 61/295, Art 20(1). See also the following provisions of the Declaration which recognize the rights indigenous peoples to pursue traditional economic activities, such as Inuit seal hunts, consistent with the EU's international obligations (i.e. GATT): Arts 19, 20, 21, 25, 27, 37, 38, 40 and 46.

${ }^{43}$ See Panel, EC - Seal Products, above n 1, paras 7.278, 7.292-7.294; Appellate Body, EC - Seal Products, above n 1, para 5.143

${ }^{44}$ Panel, EC - Seal Products, ibid, paras 7.295-7.298.

${ }^{45}$ Ibid.

${ }^{46} \mathrm{AB}, E \mathrm{C}$ - Seal Products, above n 1, paras 5.162, 5.167. This finding was in response to Norway's arguments on appeal that the Panel's analysis of the objectives of the EU Seal Regime was inconsistent with its obligation to make 'an objective assessment of the matter' in accordance with DSU Art 11 (see paras 5.150ff).

${ }^{47}$ See above $\mathrm{n} 35$.
} 
is not a binding source of law, some of its provisions are instructive when considering the objectives of the EU Seal Regime. As noted above, the UNDRIP explicitly recognises the right of indigenous communities to freely purse their traditional and other economic activities. Moreover, states are expected to take measures to facilitate those activities. Consequently, it is difficult to see how the protection of Inuit and other indigenous communities (including their right to economically benefit from their seal hunting practices) could fail to be recognised by the WTO Panel and AB as an objective of the EU Seal Regime. As elaborated on below, that failure critically impacts the analysis of the public morals exception.

\section{Narrowly Construing the Objectives of the EU Seal Regime Critically Impacts the Analysis of the Public Morals Exception}

As mentioned at the start of this comment, both the WTO Panel and AB determined that the EU Seal Regime was provisionally justified on grounds that it was put in place to protect a public moral concern for animal welfare. ${ }^{48}$ Inextricably linked to its discussion about the objectives of the EU Seal Regime, the WTO Panel's consideration of public morals centres around its discussion of the EU Seal Regime as an unnecessary obstacle to trade and subsequently informs its analysis under GATT Article XX(a). Having defined the objective of the EU Seal Regime as solely related to seal welfare, the WTO Panel considered whether that objective could be considered a moral concern as defined and applied within the EU according to its own systems and values. To do this, the WTO Panel reviewed a number of pieces of evidence, including the legislative history of the EU Seal Regime, measures taken by the EU and its member states concerning animal protection, conventions on animal welfare within the EU and various international instruments. On the basis of that evidence the WTO Panel concluded that 'animal welfare is an issue of ethical or moral nature in the [EU].' In response to arguments by the EU regarding the need to protect Inuit and indigenous community seal hunting practices, the WTO Panel found that there was not enough evidence demonstrating that the EU public attributed a higher

\footnotetext{
${ }^{48}$ In both cases, the EU Seal Regime was unable to overcome the requirements of the chapeau of GATT Art XX. In both instances, concerns were raised about the even-handedness in the design and application of the IC Exception (See Panel, EC - Seal Products, above n 1, para 7.650; AB, EC - Seal Products, above n 1, paras 5.320, 5.377-5.378).
} 
moral value to the protection of Inuit interests when compared to seal welfare. ${ }^{49}$

The AB subsequently upheld the WTO Panel's conclusion that the EU Seal Regime could be justified because it is necessary to protect public morals under GATT Article XX(a). On appeal, Norway and Canada did not challenge the WTO Panel's finding that the protection of animals (particularly seals) is a matter of public morals in the EU. Numerous other arguments were raised, including challenges to the WTO Panel's analysis of 'necessity' under GATT Article XX(a) and whether the EU Seal Regime needs to make a material (not just some) contribution to its stated animal welfare goals. But, for all of those arguments, little mention is made of the interests of Inuit or other indigenous communities. This is an inevitable consequence of narrowly construing the objectives of the EU Seal Regime and, while it may at first seem to be an insignificant detail, it critically impacts the analysis of the public morals exception.

Recall that the necessity analysis under GATT Article XX involves 'weighing and balancing' a series of factors, including the importance of the objective and the contribution of the measure to that objective. ${ }^{50}$ Now consider an alternative scenario in which the WTO Panel and AB considers that the EU Seal Regime has multiple objectives (i.e. seal welfare and the protection of Inuit seal harvesting) and that both objectives are tied to moral concerns. Under the GATT Article $\mathrm{XX}$ test for necessity, both of those objectives and the corresponding competing moral concerns at issue - in this case animal welfare and protecting (or at least not destroying) seal hunts by Inuit and other indigenous community - would be assessed and weighed together. In so doing, it is conceivable that the WTO Panel and the $\mathrm{AB}$ could rank the objectives of the EU Seal Regime and, relying on the EU's arguments in the case, determine that the protection of seal hunts by Inuit and other indigenous communities is more important than animal welfare. In that alternative scenario, it seems highly unlikely that either the WTO Panel or the $\mathrm{AB}$ would still find that the EU Seal Regime contributes to that objective given findings that the IC Exception within the Regime favours the Greenlandic Inuit seal hunt.

Alternatively, it is also possible that the WTO panel and AB could conclude that neither objective is more important than the other. In such a situation,

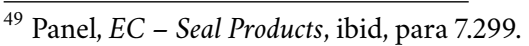

${ }^{50} \mathrm{AB}$, Korea - Beef, above n 21, para 164, AB, US - Gambling, above n 19, para 306 and AB, Brazil Retreaded Tyres, above n 21, para 182. Other factors to consider under the necessity test include the trade-restrictiveness of the challenged measure and whether there are less trade-restrictive alternatives that could make a similar contribution to the challenged measures objectives: see e.g. AB, US - Gambling, above n 19, para 307 (referring to AB, Korea - Beef, above n 21, para 166).
} 
the EU Seal Regime would need to protect both public moral concerns in order for it to be provisionally justified under GATT Article XX(a). Recall, however, the factual findings that the EU Seal Regime only made some contribution to the protection of animal welfare because (i) indigenous seal hunts employ the same 'inhumane' techniques as commercial hunts, ${ }^{51}$ and (ii) the measure permits the import of seal products into the EU for process and re-export regardless of the hunting technique employed. ${ }^{52}$ Consider also the WTO Panel's finding that the IC Exception was designed to exclude seal products from the Canadian Inuit due to their reliance on commercial processing and distribution chains that would be unavailable once the EU's ban was put into effect. ${ }^{53}$ Again, it is difficult to envisage an outcome in which the EU Seal Regime could be found to be contributing to both animal welfare and the protection of the Inuit seal harvest.

Thus, under either alternative scenario, consideration of the EU Seal Regime's objective to protect the seal harvest by Inuit and other indigenous communities would likely result in a finding that the EU Seal Regime is not necessary to protect public moral concerns within the EU. In contrast are the actual decisions of the WTO Panel and AB, which found that the EU Seal Regime was provisionally justified under GATT Article XX(a) but unable to meet the requirements of the chapeau. Under the alternative scenarios posited, it would not be necessary to examine whether the EU Seal Regime results in arbitrary or unjustifiable discrimination or is a disguised restriction on trade. Such a result seems more fitting for a measure put in place to protect certain interests within the EU at the expense of Canada's Inuit communities.

\section{Narrowly Construing the Objectives of the EU Seal Regime Legitimises a Measure that Operates in a Morally Imperialistic Manner}

By framing the GATT Article XX(a) analysis entirely in terms of the legitimacy of animal welfare as a moral concern, both the WTO Panel and AB subordinate the moral concerns of Inuit and other indigenous sealing communities to those of the EU. Particularly troubling is the WTO Panel's assessment that the evidence in the case did not demonstrate that the EU public attributes a higher moral value to the protection of Inuit interests when compared to seal welfare. By

\footnotetext{
${ }^{51}$ Panel, EC - Seal Products, above n 1, paras 7.444-7.448.

${ }^{52}$ See e.g. ibid, paras $7.53,7.455$.

${ }^{53}$ Ibid, paras 7.314-7.315.
} 
accepting that the EU public is the only reference point from which to assess the existence of a moral concern, the interests of indigenous communities are marginalised. The inevitable result is that a state implementing a trade measure, which in this case is also the historically dominant culture, effectively defines the relevant moral concerns to the exclusion of minority interests. Thus, by avoiding complicated questions about balancing moral concerns for seal welfare against moral concerns about the protection of indigenous communities (see section 6), the WTO Panel and AB give legitimacy, albeit unintentionally, to a measure that operates in a morally imperialistic matter. Under the EU Seal Regime, the dominant EU culture defines and imposes its morality onto the foreign Canadian Inuit communities without any meaningful consideration of their interests and even if it means the destruction of a traditional economy.

\section{Conclusion}

At the time of writing this comment, how the EU will respond to the AB's decision remains uncertain. Given some of the findings of the WTO Panel and $\mathrm{AB}$ in this case, it is difficult to imagine the EU implementing anything other than a more restrictive ban that effectively precludes indigenous populations in sealing nations, including Canada, from trading seal products outside their own communities. Thus, the decision will likely only embolden the EU's initiative to deny market access to seal products under the guise of animal welfare concerns. To some, this recent addition to WTO jurisprudence is seen as a welcome development insofar as it facilitates pluralistic state policy-making within an institution that is continually working to balance goals of trade liberalisation, while at the same time maintaining some amount of regulatory autonomy for WTO members. ${ }^{54}$ For others, the WTO's decision creates a sense of unease.

While there is no question that a concern for animal welfare is one of the motivations behind the EU Seal Regime, it was not the only consideration. Indeed, a review of the EU Seal Regime that was eventually approved by the European Parliament and the Council of Ministers demonstrates that it was a legislative attempt to balance conflicting interests within the 28-member state union. Contrary to the express text of that legislation, however, the WTO Panel and $\mathrm{AB}$ narrowly determined that the main or principal objective of the EU Seal

\footnotetext{
${ }^{54}$ See e.g. R Howse \& J Langille, 'Permitting Pluralism: The Seal Products Dispute and Why the WTO Should Accept Trade Restrictions Justified by Noninstrumental Moral Values' (2012) 37 Yale JIL 367.
} 
Regime is animal welfare. As outlined above, the Panel and $A B$ pay little attention to the interests of indigenous communities in their decisions. Most unsettling is the narrow construction of the intended objectives of the EU Seal Regime. By confining the rationale of the EU Seal Regime to animal welfare, the Panel and $\mathrm{AB}$ avoid complicated questions about balancing moral concerns for seal welfare against moral concerns about the protection of indigenous communities. This results in analytical shortcomings that are critical to the analysis of the EU Seal Regime under the public morals exception. Moreover, and perhaps more importantly, narrowly construing the objectives of the EU Seal Regime legitimises a measure that operates in a morally imperialistic manner. Under the EU Seal Regime a dominant culture defines and imposes its morality onto a foreign indigenous culture without any meaningful consideration of their interests and even if it means destroying their ability to benefit from their traditional seal hunting practices. 